\title{
The use of aluminum hydroxide as adjuvant modulates the antibody response to food allergens
}

\author{
Katrine Lindholm Bøgh", Mie Scharff Andreasen, Charlotte Bernhard Madsen \\ From Food Allergy and Anaphylaxis Meeting 2014 \\ Dublin, Ireland. 9-11 October 2014
}

\section{Background}

Aluminum hydroxide $\left(\mathrm{Al}(\mathrm{OH})_{3}\right)$ is a widely used adjuvant for induction of experimentally Th2 responses in animals and hence has been used for examination of food protein allergenicity. Further $\mathrm{Al}(\mathrm{OH})_{3}$ is used as an adjuvant for subcutaneous allergy vaccines. In the present study we investigated the impact of the use of $\mathrm{Al}(\mathrm{OH})_{3}$ on the antibody specificity to the cow's milk allergens $\beta$-lactoglobulin and $\alpha$-lactalbumin.

\section{Methods}

The cow's milk proteins were denatured by reduction and alkylation. Brown Norway rats were immunised intraperitoneally with either the native or the denatured form of the allergen with or without $\mathrm{Al}(\mathrm{OH})_{3}$ as adjuvant. The specific IgG1 and IgE antibody responses were analysed against the native as well as the denatured allergen by different ELISAs.

\section{Results}

Denaturation of proteins will result in the unfolding of the native structure. Thus, while linear epitopes are maintained, there will be a consequential loss of conformational epitopes. Therefore examining the antibody reactivity against both the native and the denatured form of the proteins, will allow for examination of the relative proportions between antibodies raised against linear and conformational epitopes. This study showed that the native allergens had a greater sensitising capacity than their denatured counterpart. While native allergens primarily induced antibodies against conformational epitopes, the denatured allergens only induced antibodies against linear epitopes. However, most interestingly, this

National Food Institute, Technical University of Denmark, Søborg, Denmark study showed that the use of $\mathrm{Al}(\mathrm{OH})_{3}$ modulated the antibody response, increasing the percentage of antibodies raised against linear epitopes.

\section{Conclusion}

The study demonstrated that adsorption of proteins to $\mathrm{Al}(\mathrm{OH})_{3}$ changes the antibody specificity to the proteins. As this modulation of the antibody response was most pronounced for rats immunised with the native form of the allergen, we hypothesis that $\mathrm{Al}(\mathrm{OH})_{3}$ causes adsorption-induced changes in the protein structure, probably leading to an unfolding of the protein.

Published: 30 March 2015

doi:10.1186/2045-7022-5-S3-P100

Cite this article as: Bøgh et al:: The use of aluminum hydroxide as adjuvant modulates the antibody response to food allergens. Clinical and Translational Allergy 2015 5(Suppl 3):P100.

Submit your next manuscript to BioMed Central and take full advantage of:

- Convenient online submission

- Thorough peer review

- No space constraints or color figure charges

- Immediate publication on acceptance

- Inclusion in PubMed, CAS, Scopus and Google Scholar

- Research which is freely available for redistribution 